\title{
Cytohistological Distribution of Some Metabolites in the Shoot Apex of Raphanus sativus L.
}

\author{
Manju Sharma and K. C. Sharma \\ Department of Botany, University of Rajasthan, Jaipur-302004, India
}

Accepted May 7, 1988

There has been an increasing attempt on the part of investigators to explore changes in the relative distribution of metabolites in the cells of different zones of the shoot apex during ontogeny and to correlate the results with anatomical and histological changes. Sharma et al. (1986) suggested the importance of histochemical analysis of zonation studying the shoot apical organization in Acacia. The shoot apex showed different zonation patterns with histochemical and normal anatomical stains. The data on distribution patterns of RNA, DNA, total proteins and insoluble polysaccharides in different zones of the shoot apex from embryonal to flowering stages in Raphanus sativus Linn. are reported here.

\section{Materials and methods}

Shoot apices of Raphanus sativus Linn. were collected from mature embryos, at $24 \mathrm{hrs}$. intervals for the first seven days after seed wetting and subsequently at one week intervals till flowering. About 15-20 samples from each collection were fixed both in FAA and Carnoy's solution-b (ethyl alcohol, glacial acetic acid and chloroform, $6: 3: 1$ ), processed through TBA series, embedded in paraffin and sectioned at 6-7 $\mu \mathrm{m}$. The following staining procedures were used: RNA-pyronin-Y (Tepper Gifford 1962) with perchloric acid as control (Erickson et al. 1949); DNA-Feulgen nuclear reaction (Gomori 1952) with perchloric acid as control; total proteins-mercuric bromophenol blue (Mazia et al. 1953) with acetylation as control (Jensen 1962); insoluble polysaccharides-periodic acid Schiff's reaction (Hotchkiss 1948, McManus 1948) leaving out the periodic acid treatment as control.

\section{Observations}

The plumular and vegetative apices show a tunica-corpus organization (Figs. 1-4) and the reproductive apices a mantle-core organization (Figs. 5-6). Based on staining intensities, a well defined cytohistological zonation is seen in the vegetative and reproductive apices stained for RNA and total proteins. The zonation is first seen in the apices at one day after seed wetting. The corpus may be demarcated into a lightly stained central mother cells zone (CMZ) with irregularly arranged cells proximal to the 2-3 layered tunica, densely stained peripheral zone (PZ) with 3-5 regular cell layers on the apical flanks and lighter pith meristem (PM) with a group of cells subjacent to the CMZ.

$R N A$ : The plumular apices show uniform staining in the single-layered tunica and corpus. Both nuclear and cytoplasmic RNA are present in both the zones.

In vegetative apices the $\mathrm{PZ}$ and peripheral tunica cells show more pyroninophilia than the axial tunica, CMZ and PM. The denser staining in the PZ is more in the cytoplasm than in the nucleus (Figs. 2-4). There is a general increase in depth of staining in all the zones of the inflorescence apex. The peripheral mantle layers show deeper staining for cytoplasmic as well as nuclear RNA followed by the core in the staining intensity (Figs. 5 and 6). More cyto- 
plasmic than nuclear RNA is present in the mantle.

$D N A$ : The apex at all the developmental stages shows uniformly densely stained nuclei in all the zones (Fig. 10). The cells in bracts, florets and primordia of different floral parts show deeper stained nuclei

Total proteins: Both nuclear and cytoplasmic proteins are present in the meristematic cells of the plumular apex (Fig. 7). The vegetative apex shows a distinct zonate distribution of both nuclear and cytoplasmic proteins with lightly stained CMZ and darkly stained PZ (Fig. 8).

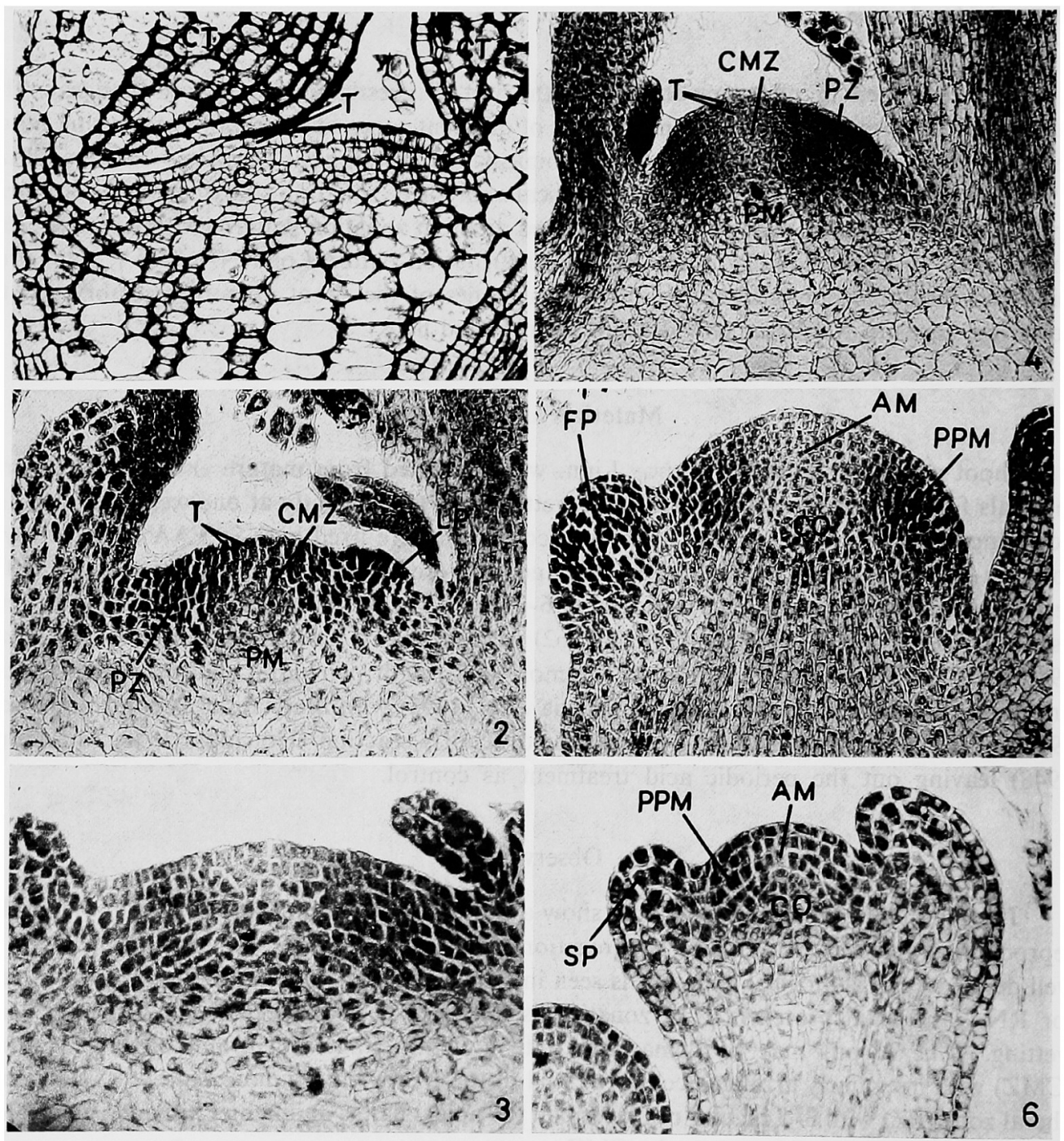

Figs. 1-6. Median longitudinal sections of the shoot apices stained for insoluble polysaccharides and RNA. 1, plumular apex stained for insoluble polysaccharides, showing tunica-corpus organization without cytohistological zonation. $\times 500$. 2-4, vegetative apices at minimal, mid and maximal stages of plastochron respectively, stained for RNA and showing well demarcated zones (tunica, CMZ, PZ, PM) in the corpus. $\times 250, \times 250, \times 200.5$, inflorescence apex with floret primordia, stained for RNA and showing mantle-core organization. $\times 200$. 6, floret apex with sepal primordia, stained for RNA. $\times 325$. AM: axial part of mantle, C: corpus, CMZ: central mother cell zone, $\mathrm{CO}$ : core, CT : cotyledon, FP: floret primordium, LP: leaf primordium, PM : pith meristem, PPM: peripheral part of mantle, PZ: peripheral zone, SP: sepal primordium, T: tunica layers. 
The reproductive apices show marginally lighter axial mantle and core than the peripheral mantle (Fig. 9).

Insoluble polysaccharides: The outermost cell walls of the tunica cells are darker stained in the plumular and vegetative apices (Fig. 1). Cell walls in the mantle layers take a darker stain than the core in the inflorescence and floret apices.

\section{Discussion}

There are reports of well marked cytohistological zonation (Gifford 1950, Ramji 1961) as well as reports denying the presence of zonation in the shoot apices studied with normal mor-
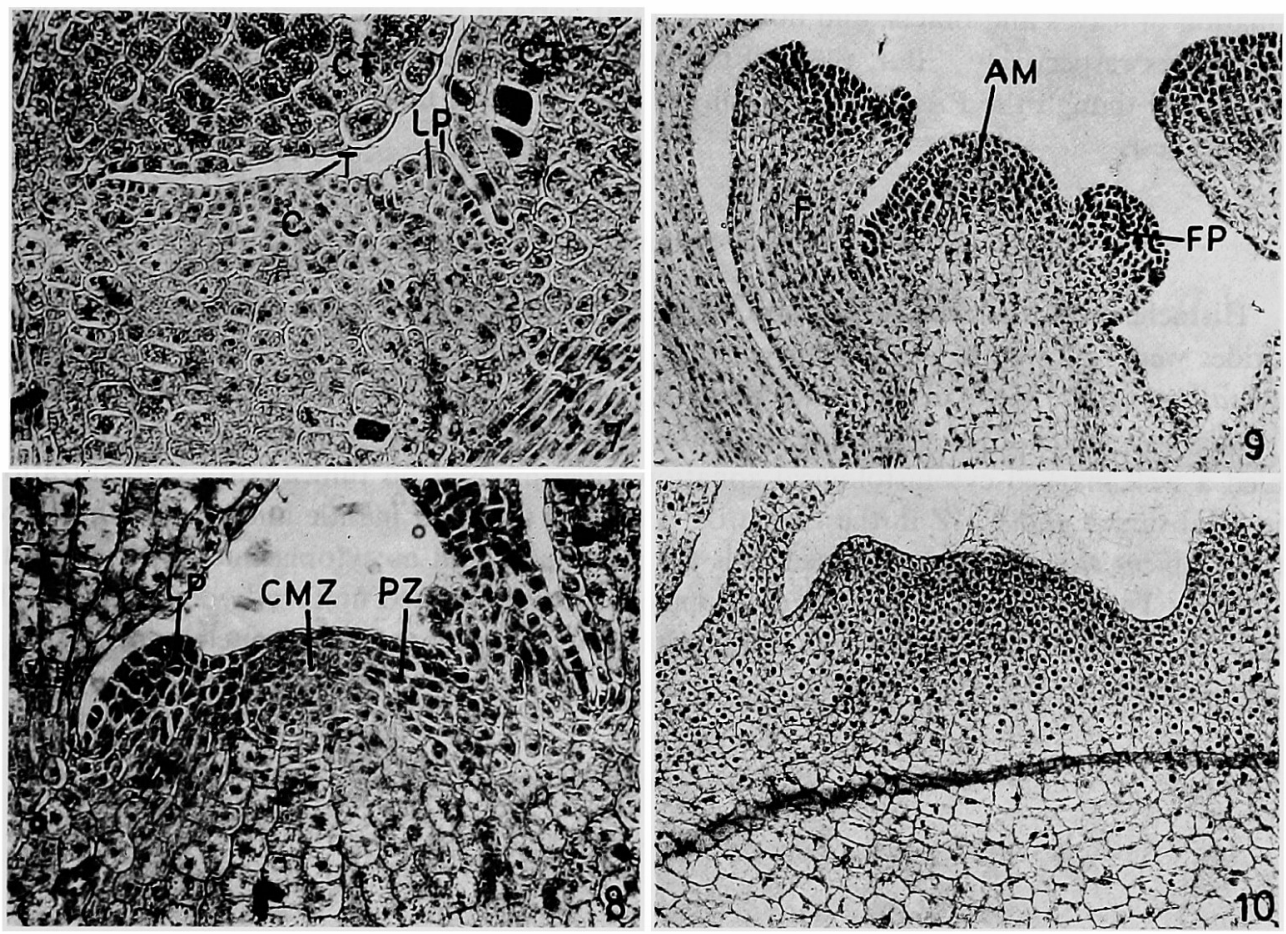

Figs. 7-10. Median longitudinal sections of the shoot apices stained for total proteins and DNA. 7, plumular apex with first leaf primordium initiating, stained for total proteins. $\times 300$. 8 , vegetative apex stained for total proteins. $\times 250.9$, inflorescence apex stained for total proteins. $\times 150$. 10, vegetative apex stained for DNA. $\times 250$. AM: axial mantle, C: corpus, CMZ: central mother cell zone, CT: cotyledon, F: floret, FP: floret primordium, LP: leaf primordium, LP $_{1}$ : first leaf primordium, PZ: peripheral zone, T: tunica layers.

phological stains (Ramji 1960, Tucker 1962). Shoot apices showed no zonation with anatomical stains and clear cytohistological zonation with histochemical stains in Acacia nilotica (Sharma et al. 1986). The cytohistological zonation as revealed by staining for RNA and total proteins in the present study, developed during the first week of vegetative growth, persists till flowering - a lightly stained axial zone is present in the inflorescence and floret apices. This has also been reported by Bernier (1962). But the apices stained for DNA in the present study showed equal intensity of staining in the nuclei of all the zones. This indicates that zonation noticed with stains for RNA and total proteins can mainly be attributed to variations in the depth of staining of the cytoplasm. 
Biochemical differences between different zones of the apex particularly between peripheral zone (PZ) and axial zone (CMZ) have been correlated with the intensity of staining in these zones (Cecich et al. 1972, Riding and Gifford 1973). Riding and Gifford have also emphasized the importance of RNA in the formation of lateral organs and determination of zonation in the shoot apices. This is often followed by an increase in total proteins and histones. The data presented here support the above.

Buvat $(1952 a, b)$ and others considered that the méristème d'attente (comparable to the $\mathrm{CMZ}$ ) has no organogenetic or histogenetic role during vegetative growth and becomes active in the reproductive apex. The lighter axial zone as reported in the reproductive apices here was not seen by them. Deeper staining for both nuclear as well as cytoplasmic RNA and total proteins in the $\mathrm{PZ}$ and peripheral mantle layers indicates the greater role of these zones in the formation of leaves and bracts, and florets or floral parts in the vegetative and reproductive or floret apices respectively But, the uniform distribution of DNA indicates that the CMZ is not inactive though the $\mathrm{PZ}$ and the peripheral mantle layers may be more active in terms of organogenesis.

\section{Summary}

Histochemical distribution patterns of RNA, DNA, total proteins and insoluble polysaccharides were followed from the embryonal to the flowering stages of the shoot apex in Raphanus sativus Linn. Cells in the tunica and corpus in the plumular apex stained uniformly for all the above metabolites. Staining for RNA and total proteins in the vegetative apices revealed a well marked cytohistological zonation superimposed on tunica-corpus organization. The axial tunica and CMZ in the vegetative apex and the axial mantle and core in the reproductive apices showed lighter stained cells for nuclear as well as cytoplasmic RNA and total proteins. The shoot apex at all the developmental stages stained uniformly densely in all the zones for both DNA and insoluble polysaccharides with deeper stained nuclei and cell walls respectively.

\section{Acknowledgements}

We wish to acknowledge the help given by Dr. (Mrs.) A. Pillai.

\section{Literature cited}

Bernier, G. 1962. Evolution of the apical meristem of Sinapis alba L. (long-day plant) in long days, in short days and during the transfer from short days to long days. Caryologia 15: 303-325.

Buvat, R. 1952a. Structure, évolution et fonctionnement du méristème apical de quelques dicotylédones. Ann. Sci. Nat. Bot. 11, 13: 198-300.

- 1952b. L'organisation des méristèmes apicaux chez les végétaux vasculaires. Union des Nat. Bull. 40: 54-66.

Cecich, R. A., Larsten, N. R. and Miksche, J. P. 1972. A cytophotometric study of nucleic acid and proteins in the shoot apex of white spruce. Am. J. Bot. 59: 442-449.

Erickson, R. O., Sax, K. B. and Ogur, M. 1949. Perchloric acid in the cytochemistry of pentose nucleic acid. Science 110: $472-473$.

Gifford, E. M. Jr. 1950. The structure and development of the shoot apex in certain woody Ranales. Am. J. Bot. 37: 595-611.

Gomori, G. 1952. Microscopic Histochemistry. Principles and Practice; Univ. of Chicago Press, Chicago.

Hotchkiss, R. D. 1948. A microchemical reaction resulting in the staining of polysaccharide structure in fixed tissue preparations. Arch. Biochem. 16: 131-141.

Jensen, W. A. 1962. Botanical Histochemistry. W. H. Freeman \& Co., San Francisco.

Mazia, D., Brewer, P. A. and Alfert, M. 1953. The cytochemical staining and measurements of protein with 
mercuric bromophenol blue. Biol. Bull. 104: 57.

McManus, J. F. A. 1948. Histological and histochemical uses of periodic acid. Stain Tech. 23: 99-108.

Ramji, M. V. 1960. The structure of the shoot apex and leaf initiation in Polyalthia longifolia. Proc. Indian Acad. Sci. 51B: 227-241.

- 1961. Ontogenetic studies on Sarcandra irvingbaileyi Swamy. I. The structure of the shoot apex and ontogeny of leaf. Proc. Indian Acad. Sci. 53B: 20-35.

Riding, R. T. and Gifford, E. M. Jr. 1973. Histochemical changes occurring at the seedling shoot apex of Pinus radiata. Can. J. Bot. 51: 501-512.

Sharma, K. C., Sharma, M. and Pillai, A. 1986. Histochemical analysis of zonation in the shoot apex of Acacia nilotica (L.) Del. J. Indian Bot. Soc. 65: 170-174.

Tepper, H. B. and Gifford, E. M. Jr. 1962. Detection of ribonucleic acid (RNA) with pyronin stain. Stain Tech. 37: 52.

Tucker, S. C. 1962. Ontogeny and phyllotaxis of terminal vegetative shoots of Michelia fuscata. Am. J. Bot. 49: 722-737. 